\title{
Quantification of Incremental Benefits and Change in Input Use Pattern under Laser Land Levelling in comparison with Conventional Land Levelling in Haryana
}

\author{
Dinesh Kumar ${ }^{1}$, Dalip Kumar Bishnoi ${ }^{2}$, Raj Kumar ${ }^{3 *}$, Sumit ${ }^{2}$ and A.K. Dhaka ${ }^{4}$
}

${ }^{1}$ Ph.D. Scholar, Department of Agricultural Economics, CCSHAU, Hisar, India

${ }^{2}$ Assistant Scientist, Department of Agricultural Economics, CCSHAU, Hisar, India

${ }^{3}$ Senior Research Fellow, Department of Agricultural Economics, CCSHAU, Hisar, India

${ }^{4}$ Assistant Professor, Department of Agronomy, CCSHAU, Hisar, India

*Corresponding author: rajkumarkashyap301@gmail.com (ORCID ID: 0000-0003-3089-6234)

Received: $13-03-2021$

Revised: 20-05-2021

Accepted: $10-06-2021$

\begin{abstract}
The investigation aimed to find monetary benefits of Laser Land Levelling (LLL) compared to conventional land leveling (CLL) in Karnal and Sirsa district of Haryana. These two districts were selected purposively because these have the highest area under paddy-wheat and cotton-wheat cropping patterns, respectively. THE Equation of Aryal et al. (2014) was explicitly used to estimate incremental benefits from laser land leveling. Also, input use pattern of machine labor, seed, plant protection chemicals, human labor, yield, and irrigation was considered. In the paddy-wheat cropping pattern of Karnal district, the annual net benefits of using laser land levelling were estimated to be ₹ 11450.81. In contrast, per LLL operation, net benefits were estimated to be ₹ 34352. Similarly, on the same lines in the cotton-wheat cropping pattern of Sirsa district, the annual net benefits of LLL were estimated to be $₹ 7212.61$. In contrast,per LLL operation, net benefits were estimated to be ₹ 28850. As far as the input use pattern is concerned, the study showed that machine labour and yield increased under LLL while in both districts. In contrast, all other inputs i.e., seed, fertilizer, human labor, plant protection, chemicals, irrigation, were reduced, showing resource conservation potential of LLL. Hence, the study recommended adopting this resource conservation technology and tapping its potential benefits so that farmers may get benefitted from this ultimate technology.
\end{abstract}

Highlights

( Adopting Laser land levelling helps in conserving irrigation and fertilizer significantly, and net returns are more under compared to conventional land levelling.

Keywords: Incremental benefits, input use, laser land leveling

Subsistence agriculture has turned into intensive agriculture with the coming of the green revolution in 1960. Intensive use of fertilizers and irrigation by farmers has created pressure on the ground water table,, showing declining trends for the last two decades. Northern plains, specifically Haryana and Punjab, are called "'food baskets of India"" because they ensure the food security of the entire nation. We can't compromise producing less intensively from this zone. Some potential benefits of Laser land leveling are: It is a climate-smart and energy-efficient resource conservation technology that increases net returns, B-C ratio, and decreases cost of cultivation and input use (especially of

\footnotetext{
How to cite this article: Kumar, D., Bishnoi, D.K., Kumar, R., Sumit and Dhaka, A.K. (2021). Quantification of Incremental Benefits and Change in Input Use Pattern under Laser Land Levelling in comparison with Conventional Land Levelling In Haryana. Economic Affairs, 66(2): 259263.

Source of Support: None; Conflict of Interest: None
} 
water and fertilizer). It supports diversification because it helps in good water control, which is required in vegetables. Also, raised beds are easy to create on leveled field. It increased cultivable area because of a reduction in bunds in the field. Also, it helps in better weed management. Laser land leveling (LLL) employs because the owner of laser land levelers hires drivers at peak season (positive labor displacement). This technology is not biased towards large farmers, and it is scale-neutral technology.

Almost every category of farmers has adopted this technology. Some limitations of using LLL are: Stubbles must be burnt or decomposed off before using laser land leveling. Better weed management (especially in cotton) leads to labor unemployment doing manual weeding (negative labor displacement). Also, it is more economical to use laser land leveling on big farm size because, on small farms, rig is continuously adjusted. Irrigated area is a pre-requisite for using laser land leveling. So, that rainfed area of the state will not get potential benefits from this technology. So, it was felt imperative to introduce a resource conservation technology (RCT) that can help inefficient use of water and fertilizers specifically in rice-wheat cropping pattern. Laser leveling is the most effective RCT to cure this problem of excessive use of inputs. Two techniques of leveling are practiced in Haryana i.e., laser land leveling and conventional land leveling. Cost of production is rising, and yield is stagnating due to the rising cost of inputs and fuel, which eventually mismatch between demand and supply. The productivity of soil is also showing declining trends. Existing Technologies of crop production are resulting in over utilization of scarce resources and leading to inefficiency of production. Therefore, the study tried to quantify the economic benefits of using laser land levelling compared to conventional land leveling because laser land levelling can increase crop productivity, conserve scarce resources, and increase water and fertilizer use efficiency.

\section{MATERIALS AND METHODS}

Laser leveling here means leveling of field within a certain degree of the desired slope using laserguided scrapper. Primary data were collected from
120 respondents from two districts i.e. Karnal and Sirsa. These districts were selected purposively based on the highest area under paddy-wheat and cotton-wheat cropping patterns, respectively. Secondary data were collected from various published and unpublished sources i.e. Statistical Abstract of Haryana, Agricultural Statistics at a Glance. From each district, sixty (60) respondents have interviewed through pre-tested questionnaire. Out of total respondents, forty (40) were adopters of laser land leveling, and twenty (20) were -nonadopters (Adopters of CLL).One Man day was assumed to be equivalent to 8 hours of work by a man, 10 hours by a woman, and 12 hours by a child. For simplicity of calculations, fertilizer and plant protection chemicals were added under one heading. Net benefits per year and laser land leveling operation were calculated separately. To calculate incremental benefits Aryan et al. (2014) equation was used, which has the following assumptions:

1. Efficacy of one laser land leveling operation lasts for 3 years in case of Karnal and 4 years ins for 3 years in Karnal and 4 years in Sirsa district.

2. It was assumed that during these 3 years and four years, farmers strictly follow paddywheat and cotton-wheat cropping patterns, respectively.

3. An increase in crop pricecrop price counterbalances discounted interest rate or we can say prices of crops remain constant.

4. MSP was taken as price of crop to estimate benefit stream.

\section{Aryal et al. (2014) equation for incremental benefits of laser land levelling}

Incremental benefit $(\odot / L L L)=$

$$
\sum\left\{P_{w i}^{*} Y_{W}+P_{R i}^{*} Y_{R}\right\}-C_{L} H_{L}
$$

Where, $P_{w}=$ Price of wheat; $Y_{W}=$ Increment in wheat productivity; $P_{R}=$ Price of rice; $Y_{R}=$ Increment in rice productivity; $C_{L}=$ Cost of hiring laser leveling per hour; $H_{L}=$ Time required to laser level the field; $i=$ $1,2,3 \ldots n$ (frequency of LLL operation) 


\section{RESULTS AND DISCUSSION}

\section{Incremental benefits in laser land leveling (LLL) vis-a-vis conventional land leveling (CLL)}

Incremental benefits in laser land leveling over conventional land leveling were calculated by using Aryal et al. (2014) equation. One basic assumption applied was that increase in the price of crops counterbalances discount interest rates over time. It means the prices of crops remain constant and almost equal to MSP.

Table 1: Benefits of laser land leveling in Karnal district of Haryana

\begin{tabular}{lll}
\hline $\begin{array}{l}\text { S1. } \\
\text { No. }\end{array}$ & Particulars & $\begin{array}{l}\text { Incremental } \\
\text { profit }\end{array}$ \\
\hline 1 & Price of Wheat $(₹ / \mathrm{kg})$ & 19.25 \\
2 & Price of Paddy $(₹ / \mathrm{kg})$ & 33.70 \\
3 & Incremental yield of Wheat $(\mathrm{kg} / \mathrm{ha})$ & 261.01 \\
4 & Incremental yield of Paddy $(\mathrm{kg} / \mathrm{ha})$ & 213.74 \\
5 & Benefit per year from Wheat $(₹ / \mathrm{kg})$ & 5024.47 \\
6 & Benefit per year from Paddy $(₹ / \mathrm{kg})$ & 7203.00 \\
7 & Number of years LLL applicable & 3.00 \\
8 & Benefit per LLL operation & 36682.43 \\
9 & Cost of hiring LLL per hour & 800.00 \\
10 & Average time to level one hectare & 2.91 \\
11 & Cost of LLL (₹/ha) & 2330.00 \\
12 & Net benefit per year (₹) & 11450.81 \\
13 & Net benefit per LLL operation $(₹)$ & 34352.43 \\
\hline
\end{tabular}

Incremental benefits of laser land leveling technology in Karnal and Sirsa are presented in Table 1 and 2. In Karnal district, the effect of one laser land leveling continues for three years, and on average, 2.91 hours are required to level one hectare of the field with hiring cost of laser land leveling @ ₹ 800 per hour. Hence, one-hectare laser leveling costs were ₹ 2330. The market price of wheat and paddy, was ₹ $19.25 / \mathrm{kg}$ and ₹ $33.70 / \mathrm{kg}$, respectively. Hence, vield differential in wheat and paddy was 261.01 and $213.74 \mathrm{~kg}$ per hectare, respectively. Hence, an annual net benefit of using laser land leveling was estimated to be ₹ 11450.81 , while, per laser land leveling operation, the net benefit was worked out to be ₹ 34352.43 .

In Sirsa district, the effect of one laser land leveling continuous for four years, and on average, 2.89 hours are required to level one hectare of the field with hiring cost of laser land leveling @ ₹ 800 per hour. Hence, one-hectare laser leveling cost were estimated to be ₹ 2319.69. The market price of cotton and wheat was worked out to be $₹ 54.05 / \mathrm{kg}$ and $₹ 19.25 / \mathrm{kg}$, respectively. Per hectare yield differential in cotton and wheat was observed at 55.06 and $250.21 \mathrm{~kg}$, respectively. Hence, annual net benefits using laser land leveling were found to be ₹ 7212.61 while per laser land leveling operation, the net benefit was estimated to be ₹ 28850.45 .

Table 2: Benefits of laser land levelling in Sirsa district of Haryana

\begin{tabular}{lll}
\hline $\begin{array}{l}\text { S1. } \\
\text { No. }\end{array}$ & Particulars & $\begin{array}{l}\text { Incremental } \\
\text { profit }\end{array}$ \\
\hline 1 & Price of Cotton $(₹ / \mathrm{kg})$ & 54.05 \\
2 & Price of Wheat $(₹ / \mathrm{kg})$ & 19.25 \\
3 & Incremental yield of Cotton $(\mathrm{kg} / \mathrm{ha})$ & 55.06 \\
4 & Incremental yield of Wheat $(\mathrm{kg} / \mathrm{ha})$ & 250.21 \\
5 & Benefit per year from Cotton $(₹ / \mathrm{kg})$ & 2976.00 \\
6 & Benefit per year from Wheat $(₹ / \mathrm{kg})$ & 4816.54 \\
7 & Number of years LLL applicable & 4.00 \\
8 & Benefit per LLL operation & 31170.14 \\
9 & Cost of hiring LLL per hour & 800.00 \\
10 & Average time to level one hectare & 2.89 \\
11 & Cost of LLL (₹/ha) & 2319.69 \\
12 & Net benefit per year (₹) & 7212.61 \\
13 & Net benefit per LLL operation & 28850.45 \\
\hline
\end{tabular}

\section{Input use patterns in laser land leveling vis-a- vis conventional land leveling}

It is clearly evident from table 3 and 4 that an increase in machine hours and yield and decrease in inputs use under laser land levelling indicate its resource conservation potential.

\section{Input use pattern in Karnal district of Haryana}

In wheat, machine hours and yield increased by 11.36 percent and 4.86 percent, respectively. On the other hand, a decrease in the use of human labor, seed, fertilizer, plant protection chemicals, and irrigation was observed up to level up 7.06, 4.06, $4.68,4.16$, and 20.03 percent, respectively under laser land leveling as compared to conventional land leveling. THE Highest reductions were observed in irrigation. Whereas, in the case of paddy, machine hours and yield increased by 7.87 and 5.02 per cent, 
Table 3: Input use pattern under laser land leveling and conventional land leveling in paddy-wheat cropping system in Karnal district of Haryana

\begin{tabular}{lllllll}
\hline \multirow{2}{*}{ Particulars } & \multicolumn{3}{c}{ Wheat } & \multicolumn{3}{c}{ Paddy } \\
\cline { 2 - 7 } & LLL & CLL & Per cent & LLL & CLL & Per cent \\
\hline Machine labour (hours) & 18.73 & 16.82 & 11.36 & 18.15 & 16.83 & 7.87 \\
Human labour (man days) & 85.06 & 91.52 & -7.06 & 102.04 & 110.68 & -7.81 \\
Seeds (kg) & 105.95 & 110.44 & -4.06 & 14.64 & 15.24 & -3.93 \\
Fertilizer (kg) & 495.04 & 519.35 & -4.68 & 411.61 & 454.18 & -9.37 \\
PPC (g) & 418.66 & 436.81 & -4.16 & 510.44 & 533.42 & -4.31 \\
Irrigation (hours) & 40.92 & 51.17 & -20.03 & 107.64 & 160.06 & -32.75 \\
Yield (qt) & 56.33 & 53.72 & 4.86 & 44.68 & 42.54 & 5.02 \\
\hline
\end{tabular}

Table 4: Input use pattern under laser land levelling and conventional land levelling in cotton-wheat cropping system in Sirsa district of Haryana

\begin{tabular}{lllllll}
\hline \multirow{2}{*}{ Particulars } & \multicolumn{3}{c}{ Wheat } & \multicolumn{3}{c}{ Cotton } \\
\cline { 2 - 7 } & LLL & CLL & Per cent & LLL & CLL & Per cent \\
\hline Machine labour (hours) & 17.10 & 15.60 & 9.67 & 16.04 & 13.70 & 17.12 \\
Human labour (man days) & 83.92 & 91.60 & -8.39 & 120.15 & 133.98 & -10.33 \\
Seeds (kg) & 110.42 & 112.39 & -1.75 & 2.24 & 2.36 & -4.88 \\
Fertilizer (kg) & 587.31 & 609.73 & -3.68 & 547.78 & 575.80 & -4.87 \\
PPC (g) & 169.70 & 179.59 & -5.51 & 437.87 & 449.23 & -2.53 \\
Irrigation (hours) & 52.58 & 65.18 & -19.33 & 54.37 & 64.70 & -15.97 \\
Yield (qtl) & 51.09 & 48.59 & 5.15 & 19.65 & 19.10 & 2.88 \\
\hline
\end{tabular}

respectively. A decrease in labor, seed, fertilizer, plant protection chemicals, and irrigation was observed up to $7.81,3.93,9.37,4.31$ and 32.75 percent, respectively under laser land levelling compared to conventional land leveling. The highest reduction was observed in irrigation (Table 3).

\section{Input use pattern in Sirsa district of Haryana}

In case of wheat, machine hours and yield increased by 9.67 percent and 5.15 percent, respectively. A decrease in the use of human labor, seed, fertilizer, plant protection chemicals, and irrigation was observed up to a level of $8.39,1.75,3.68,5.51$, and 19.33 percent, respectively, under laser land leveling as compared to conventional land leveling. The highest reduction was observed in irrigation. In the Cotton machine, hours and yield increased by 17.12 and 2.8 percent, respectively. A decrease in the use of human labor, seed, fertilizer, plant protection chemicals, and irrigation was observed up to 10.33, $4.88,4.87,2.53$ and 15.97 percent respectively under laser land levelling. Irrigation was observed up to $10.33,4.88,4.87,2.53$ and 15.97 percent respectively under laser land levelling compared to conventional and levelling. Highest reduction was observed in irrigation (Table 4).

\section{CONCLUSION}

It can be validated from the results of the study that the adoption of laser land leveling increases water and fertilizer use efficiency. Study revealed that yield and machine hours were increased under laser land leveling while yield and machine hours were increased under laser land leveling while all other inputs were reduced. Maximum reductions were reported in irrigation which was 20.03 and 19.33 percent in paddy-wheat and cottonwheat cropping patterns. Also, with minimal cost of operation that is ₹ 800 per hour, ₹ 34352 and $₹ 28850$ net benefits per laser land leveling operation were realized under paddy-wheat and cotton-wheat cropping pattern, respectively. Thus, laser land leveling helps conserve the most precious resource on planet Earth i.e., water. Keeping in mind rising cost and stagnation of yield, laser land leveling is an effective climate-smart technology that can help 
inefficient utilization of scarce resources. Hence, the study recommended adopting this resource conservation technology and tapping its potential benefits so that farmers may get benefitted from this ultimate technology.

\section{ACKNOWLEDGEMENTS}

Authors wish to acknowledge Chaudhary Charan Singh Haryana Agricultural University and all the farmers who participated in the study and made the study successful

\section{REFERENCES}

Abdullaev, L., Hassan, M.U. and Jumaboev, K. 2007. Water saving and economic impacts of land levelling: the case study ofcotton production in Tajikistan. Irrig. Drain. Sys., 21(3-4): 251-263.

Ahmad, B., Khokhar, S.B. and Badar, H. 2001. Economics of laser land levelling in district Faisalabad. Pakistan J. Appl. Sci., 1(3): 409-412.

Ali, A., Hussain, I. and Erenstein, O. 2018. Laser-land levelling adoption and its impact on water use, crop yields and household income: Empirical evidence from the ricewheat system of Pakistan Punjab. Food Policy, 77: 19-32.

Aryal, J.P., Bhatia, M., Jat, M.L. and Sidhu, H.S. 2014. Impacts of laser land levelling in rice-wheat rotations of the Northwestern Indo-Gangetic Plains of India. In World Congress of Environmental and Resource Economists, June 28 - July 2, 2014. Istanbul, Turkey.

Aryal, J.P., Rahut, D.B., Jat, M.L., Maharjan, S. and Erenstein, O. 2018. Factors determining the adoption of laser land levelling in the irrigated rice-wheat system in Haryana, India. J. Crop Improv., 32(4): 477-492.

Conservation agriculture, "Conservation Agriculture: Resource productivity and efficiency", IV World Congress on Conservation Agriculture, New Delhi, PACA, It Floor, NASC Complex, DPS Marg, Pusa, New Delhi - 110012 INDIA, 2009. Available: www.conserveagri.org, 2009.

Gill, G.J. 2014. An assessment of the impact of laser-assisted precision land levelling technology as a component of climatesmart agriculture in the state of Haryana, India. New Delhi: CIMMYT-CCAFS, Internantional Maize and Wheat Improvement Center (CIMMYT).
Jat, M.L., Gupta, R., Saharawat, Y.S. and Khosla, R. 2011. Layering precision land levelling and furrow irrigated raised bed planting: Productivity and input use efficiency of irrigated bread wheat in Indo-Gangetic Plains. American J. Plant Sci., 2(04): 578.

Kahlown, M.A., Raoof, A. and Hanif, M. 2000. Rice yield as affected by plant densities. Mona Experimental Project Bhalwal, Report No. 238.

Kaur, B., Singh, S., Garg, B.R., Singh, J.M. and Singh, J. 2012. Enhancing water productivity through on-farm resource conservation technology in Punjab agriculture. Agric. Eco. Res. Rev., 25: 79-85.

Lybbert, T.J., Magnan, N., Spielman, D.J., Bhargava, A.K. and Gulati, K. 2018. Tageting technology to increase smallholder profits and conserve resources: experimental provision of laser land-levelling services to Indian farmers. Eco. Dev. Cul. Chan., 66(2): 265-306.

Naresh, R.K., Rathore, R.S., Parvinder, K., Singh, S.P., Adesh, S. and Shahi, U.P. 2014. Effect of precision land leveling and permanent raised bed planting on soil properties, input use efficiency, productivity and profitability under maize (Zea mays)-wheat (Triticum aestivum) cropping system. Indian J. Agric. Sci., 84(6): 725-732.

Naresh, R.K., Gupta, R.K., Kumar, A., Prakesh, S., Tomar, S.S., Singh, A., Rathi, R.C., Misra, A.K. and Singh, M. 2011 Impact of laser land leveller for enhancing water productivity in Western Uttar Pradesh. Int. J. Agric. Eng., 4(2): 133-147.

Naresh, R.K., Singh, S.P., Misra, A.K., Tomar, S.S., Kumar, P., Kumar, V. and Kumar, S. 2014. Evaluation of the laser levelled land levelling technology on crop yield and water use productivity in Western Uttar Pradesh. African J. Agric. Res., 9(4): 473-478.

Sapkal, S., Kamble, B.H., Kumar, P., Kar, A. and Jha, G.K. 2019. Impact of laser land levelling in rice-wheat systems of the North-Eastern Indo-gangetic plains of India. J. Pharmacogn. Phytochem., 8(1): 764-769.

Singh, D. and Kaur, P. 2017. Problems Faced by the Farmers in Adoption of Water Saving Technologies in Sri Muktsar Sahib District of Punjab. J. Community Mobilization Sustain. Dev., 12(2): 201-206. 
